\title{
Differential Regulation of Adrenergic Receptor Development by Sympathetic Innervation
}

\author{
Beth A. Habecker, Nell M. Malec, and Story C. Landis \\ Department of Neurosciences, Case Western Reserve University School of Medicine, Cleveland, Ohio 44106
}

Rat sweat glands provide an interesting model system for a developmental study of adrenergic receptor expression because their sympathetic innervation undergoes a switch from a noradrenergic to cholinergic and peptidergic phenotype. $\alpha 1 \mathrm{~B}$, $\alpha 2 \mathrm{~B}$, and $\beta 2$ receptors are expressed in rat footpads; $\alpha 1$ and $\beta 2$ receptors are localized specifically to sweat glands, and $\alpha 2$ receptors also are expressed in other tissues. $\alpha 1$ and, to a lesser extent, $\beta 2$ receptors decrease during development, whereas $\alpha 2$ levels remain relatively constant. Decreased receptor expression is accompanied by the loss of $\alpha 1$-stimulated inositol phosphate accumulation, but no change in $\beta$-stimulated CAMP production. The number of $\alpha 1$ and $\beta 2$ receptors decreases after P21, when the sympathetic innervation no longer produces catecholamines. Neonatal sympathectomy causes a partial failure of $\alpha 1$ downregulation, but has no effect on $\beta 2$ or $\alpha 2$ receptor levels. Therefore, at least two distinct mechanisms regulate development of adrenergic receptors in sweat glands. Innervation-independent processes control developmental expression of $\alpha 1, \beta 2$, and $\alpha 2$ receptors, and an additional, innervation-dependent mechanism influences expression of $\alpha 1$ receptors. Denervation at postnatal day 20, when the sympathetic innervation is cholinergic and peptidergic, results in retention of $\alpha 1$ receptors, but cholinergic blockade begun at P20 does not. These results indicate that regulation of receptor expression in sweat glands is complex, and suggest that the innervation-dependent factors that decrease $\alpha 1$ levels during development act through a nonadrenergic, noncholinergic mechanism.

Key words: adrenergic receptors; developmental regulation; anterograde regulation; sympathetic development; autonomic nervous system; sweat glands; neurotransmitter phenotype $\alpha$ and $\beta$ adrenergic receptors mediatc the actions of norepinephrine and epinephrine on central and peripheral targets by controlling the activity of intracellular effector proteins such as adenylyl cyclase and phospholipase C $\beta$ (Gilman, 1987; Raymond et al., 1990). Regulation of adrenergic receptor expression and function has been best characterized in vitro. Prolonged exposure to adrenergic agonists induces desensitization of receptor responsiveness by uncoupling receptors from downstream signaling cascades and subsequent downregulation of receptor-binding sites and mRNA. In contrast, removal of agonist or chronic blockade results in upregulation of receptor-binding and cellular supersensitivity (Collins et al., 1991, 1992; Kobilka, 1992). Receptor desensitization and downregulation can occur by two general mechanisms. Homologous regulation affects only agonist-bound receptors and is second-messenger-independent, using G-protein receptor kinases (Inglese et al., 1993), whereas heterologous regulation is agonist-independent and mediated primarily by second messengers through the actions of protein kinases $A$ and $C$ (Collins et al., 1991, 1992). Less is known about the processes controlling increased receptor expression, but cross-talk between G-protein-coupled receptors can result in up- or downregulation of binding sites and receptor mRNA as the cell compensates for

\footnotetext{
Received July 11, 1995; revised Sept. 8, 1995; accepted Sept. 20, 1995.

This work was supported by National Institutes of Health Grants NS023678 (S.C.L.) and NS09336 (B.A.H.). S.C.L. is a McKuight Senior Neuroscience Investigator. We thank Dr. Steve Asmus for immunohistochemistry photographs, Rose Chu for assistance with preliminary experiments, Dr. Paul Ernsburger for advice, and Dr. Ruth Siegel for advice and critical reading of the manuscript.

Correspondence should be addressed to Dr. Story C. Landis, Department of Neurosciences, Case Western Reserve University School of Medicine, 10900 Euclid Avenue, Cleveland, $\mathrm{OH} 44106-4975$.

Copyright $(\mathcal{O} 1995$ Society for Neuroscience 0270-6474/95/160229-(09\$05.00/0
}

decreased or increased production of second messengers (Hadcock et al., 1991; Morris et al., 1991; Lee and Fraser, 1993). These general mechanisms act to control G-protein coupling, receptor synthesis and degradation, and receptor mRNA expression and, together with regulation of the downstream signaling components, modulate cellular responsiveness.

Although the processes involved in agonist regulation of receptor responsiveness and expression have been explored extensively in culture systems, the developmental mechanisms that control expression of adrenergic receptors in vivo are not well understood. Establishing the proper pattern of adrenergic receptor expression is crucial for autonomic control of peripheral targets, and receptor activation can regulate differentiation of target tissues. For example, overexpression of the $\beta 2$ receptor alters cardiac function in transgenic mice (Milano et al., 1994), and the activation of adrenergic receptors mediates a developmental change in the gating properties of cardiac sodium channels (Zhang et al., 1992). In addition, sympathetic activation of adrenergic receptors in rat sweat glands stimulates the production of a cholinergic differentiation factor that induces a switch in the neurotransmitter properties of the sympathetic innervation (Habecker and Landis, 1994). The resulting cholinergic innervation then induces secretory function in the developing glands, completing their differentiation (Grant et al., 1995).

Rat sweat glands provide a particularly interesting model system for a developmental study of adrenergic receptor expression because of the phenotypic switch from noradrenergic to cholinergic and peptidergic function that occurs in their sympathetic innervation (Landis and Keefe, 1983; Landis et al., 1988; Landis, 1990). Because agonist exposure regulates adrenergic receptor levels in vitro, we examined whether the loss of catecholamines 
during development altered expression of adrenergic receptors in sweat glands. In this study we show that $\alpha \mathrm{lB}, \alpha 2 \mathrm{~B}$, and $\beta 2$ receptors are expressed in rat footpads, with $\alpha 1$ and $\beta 2$ localized spccifically to swcat glands. The cxpression of each subtype is regulated in a distinct manner. Innervation-independent processes regulate developmental expression of $\alpha 1, \alpha 2$, and $\beta$ receptors, whereas an additional innervation-dependent mechanism influences expression of $\alpha 1$ receptors. Our studies indicate that the mechanisms controlling receptor expression during development in vivo are more complex than those responsible for agonistinduced receptor desensitization and downregulation, which have been characterized in vitro.

\section{MATERIALS AND METHODS}

Spraguc-Dawlcy rats were purchased from Zivic-Miller (Zelienople, PA), and chemicals were from Sigma (St. Louis, MO) except as noted. Forskolin, phenylephrine, and pargyline were from Research Biochemicals (Natick, MA); 2-\{ $\beta$-(4-hydroxy-3-[ ${ }^{125}$ I]iodophenyl)-ethylaminomethyl $\}$ tetralone ([125 I]HEAT, $2200 \mathrm{Ci} / \mathrm{mmol})$, [ $\left.{ }^{125} \mathrm{I}\right]$ pindolol $(2200 \mathrm{Ci} / \mathrm{mmol})$, $\left[{ }^{125} \mathrm{I}\right]$ cyanopindolol $\left(\left[{ }^{125} \mathrm{I}\right] \mathrm{CYP}, 2200 \mathrm{Ci} / \mathrm{mmol}\right),\left[{ }^{3} \mathrm{H}\right]$ yohimbine $(83.5$ $\mathrm{Ci} / \mathrm{mmol}$ ), $\left[\rho^{125} \mathrm{I}\right]$ iodoclonidine $\left.\left.\left({ }^{125} \mathrm{I}\right] \mathrm{PIC}, 2200 \mathrm{Ci} / \mathrm{mmol}\right),{ }^{32} \mathrm{P}\right] \mathrm{dCTP}$, and $\left[{ }^{32} \mathrm{P}\right] \mathrm{dATP}(3000 \mathrm{Ci} / \mathrm{mmol})$ were obtained from Dupont-NEN (Wilmington, DE); $\left[{ }^{3} \mathrm{H}\right]$ myo-inositol $(20.5 \mathrm{Ci} / \mathrm{mmol})$, a $\left[{ }^{3} \mathrm{H}\right]$ cAMP assay kit, the Rediprime cDNA random priming kit, and $\left[{ }^{32} \mathrm{P}\right] \mathrm{dATP}(3000 \mathrm{Ci} / \mathrm{mmol})$ were obtained from Amersham (Arlington Heights, IL). RNAzol B was obtained from Tel Test (Friendswood, TX), AG1-X8 anion exchange resin from BioRad (Richmond, CA), and GF/C filters from Whatman (Maidstone, UK). NTB-3 photographic emulsion, D-19 rapid-fix, and other photographic supplies were from Kodak (Rochester, NY). Oligonuclcotides werc gencratcd in the Department of Neurosciences, CWRU (Cleveland, OH). AMV reverse transcriptase, Taq DNA polymerase, and oligo-dT primers were from Promega (Madison, WI), and MMLV reverse transcriptase, terminal transferase, and random hexamers were from Gibco (Grand Island, NY). QuickHyb hybridization solution was from Stratagene (La Jolla, CA), and Alzet miniosmotic pumps were from Alza Corp. (Palo Alto, CA). Guinea pig antivasoactive intestinal peptide (VIP) antiserum was generated in our laboratory, rabbit anticalcitonin gene-related peptide (CGRP) antiserum was obtained from Amersham, and rhodamine isothiocyanate-conjugated goat anti-guinea pig and fluorescein-conjugated goat anti-rabbit secondary antisera were obtained from Cappell-Worthington (Durham, NC)

Reverse transcription-polymerase chain reaction. RNA was isolated from adult rat brain and from the rear footpads of rats at various stages of development, using RNAzol B (Chomczynski and Sacchi, 1987). For each reaction, $1 \mu \mathrm{g}$ of total RNA was reverse-transcribed with either AMV or MMLV reverse transcriptase, using oligo-dT or random hexamers as primers. PCR reactions were carried out with subtype-specific oligonucleotide primers for the $\alpha 1 \mathrm{~B}$ (Voigt et al., 1990), $\alpha 2 \mathrm{~B}$ (Zeng et al., 1990), $\beta 1$ (Machida et al., 1990), and $\beta 2$ (Buckland et al., 1990) receptors as described (Habecker and Landis, 1994). In addition, mRNA encoding the VIP receptor was amplified using the primers: (+)GATCCTGGTTCAGAAACTAC, (-)GATGCCAACGCCGCCACTTC (bases 1017-1036, 1269-1288) (Ishihara et al., 1992). Primers were annealed at $52^{\circ} \mathrm{C}\left(\alpha 2 \mathrm{~B}, \beta 2\right.$, VIP) or $58^{\circ} \mathrm{C}$ $(\alpha 1 \mathrm{~B}, \beta 1)$, and reactions were amplified for 35 cycles. Southern blots were probed with 30-mer antisense oligonucleotides internal to PCR primers: $\alpha 1 \mathrm{~B}$, bases $1442-1471 ; \alpha 2 \mathrm{~B}$, bases $1348-1377 ; \beta 1$, bases $930-959$ (transmembrane region, hybridizes with both $\beta 1$ and $\beta 2$ ); VIP, bases $1085-1114$. Hybridization was carried out in Quick-Hyb (Stratagene) at 58 or $64^{\circ} \mathrm{C}$ for 1 $\mathrm{hr}$, and blots were washed in $0.1 \times \mathrm{SSC} / 0.2 \%$ SDS at 22 or $45^{\circ} \mathrm{C}$ and exposed onto film.

Northern analysis. RNA was isolated using RNAzol B, and 8-10 $\mu \mathrm{g}$ samples were size-fractionated on $1.2 \%$ denaturing agarose gels and blotted overnight onto nylon membranes with $20 \times \operatorname{SSC}(1 \times=0.15 \mathrm{M}$ $\mathrm{NaCl}, 0.015 \mathrm{~m}$ sodium citrate, $\mathrm{pH} 7.0$ ). After UV cross-linking, membranes were stained with methylene blue to identify all RNA. Prehybridization was carried out in Quick-Hyb at $55^{\circ} \mathrm{C}$ for $30 \mathrm{~min}$ followed by hybridization for $1 \mathrm{hr}$ with a ${ }^{32} \mathrm{P}$-tailed 30 -mer oligonucleotide specific for the $\alpha 1 \mathrm{~B}$ receptor. Blots were washed in $0.1 \times \mathrm{SSC} / 0.1 \%$ SDS at $22^{\circ} \mathrm{C}$ and exposed onto film overnight.

Receptor autoradiography. Autoradiography was performed in a manner similar to that described by Grant et al. (1991). P10, P14, and adult rats were perfused with ice-cold PBS, and footpads were removed and frozen on dry ice. Ten micron sections were mounted onto gelatin-coated slides, stored at $-20^{\circ} \mathrm{C}$, and thawed in a vacuum dessicator for binding. For $\alpha 1$ binding, sections wcre preincubated for $10 \mathrm{~min}$ in PBS before a $60 \mathrm{~min}$ incubation in PBS with $50 \mathrm{pM}\left[{ }^{125} \mathrm{I}\right] \mathrm{HEAT}$ with or without $20 \mu \mathrm{M}$ prazo$\sin$. Sections were washed twice for $8 \mathrm{~min}$ in ice-cold PBS and rinsed in ice-cold water. A similar protocol was used for $\alpha 2$ binding, except sections were incubated in PBS containing $10 \mathrm{nM}\left[{ }^{125} \mathrm{I}\right] \mathrm{PIC}$ with or without $10 \mu \mathrm{M}$ yohimbine, washed twice for $5 \mathrm{~min}$ in ice-cold PBS, and rinsed in ice-cold water. For $\beta$ binding, sections were incubated in $50 \mathrm{pm}\left[{ }^{125} \mathrm{I}\right]$ pindolol with or without $10 \mu \mathrm{M}$ propranolol as described previously (Habecker and I andis, 1994). All sections were dried rapidly and stored in a vacuum dessicator until the addition of coverslips. Coverslips $(25 \times 77 \mathrm{~mm})$ were coated with NTB-3 emulsion diluted 1:1 with water, dried, glued to the slide with Krazy Glu, and clamped into place. Autoradiograms were developed after $2 \mathrm{~d}$ of exposure at $4^{\circ} \mathrm{C}$, and sections were stained with $0.4 \%$ cresyl violet in water. Receptors were quantified by counting grain densities with the Olympus Cue 4 image analysis system.

Ligand-binding analysis. To determine cellular levels of adrenergic receptors, the binding of adrenergic antagonists was measured in crude membrane homogenates. P21 and adult rats were killed by ether inhalation, rear footpads were removed, and the dermis and epidermis were dissected away, leaving small chunks of tissue containing sweat glands, fat cells, and connective tissue (Grant et al., 1991). Fresh tissue was collected in ice-cold $50 \mathrm{~mm} \mathrm{NaPO}_{4}, \mathrm{pH} 7.4$, and homogenized with a Brinkman polytron. Membranes were isolated by centrifugation at $18,000 \times \mathrm{g}, 4^{\circ} \mathrm{C}$, for $15 \mathrm{~min}$, and resuspended in ice-cold $50 \mathrm{~mm} \mathrm{NaPO}_{4}$ for binding reactions. Reactions were carried out in PBS containing saturating concentrations (100 pM) of $\left[{ }^{125} \mathrm{I}\right] \mathrm{HEAT}(\alpha 1 ; 2000 \mathrm{Ci} / \mathrm{mmol})$, with or without $20 \mu \mathrm{M}$ prazosin, or $\left.{ }^{125} \mathrm{I}\right] \mathrm{CYP}(\beta ; 2000 \mathrm{Ci} / \mathrm{mmol})$ with or without $20 \mu \mathrm{M}$ propranolol in a final volume of $500 \mu$ l. Reactions were incubated for 90 min at room temperature and terminated by the addition of $3 \mathrm{ml}$ of ice-cold $50 \mathrm{mM} \mathrm{NaPO}$ before filtration through GF/C glass fiber filters. $\alpha 2$-binding reactions were carried out in essentially the same manner, using $10 \mathrm{nM}\left[{ }^{3} \mathrm{H}\right.$ ]yohimbine $(83.5 \mathrm{Ci} / \mathrm{mmol})$ with or without $20 \mu \mathrm{M}$ yohimbine in $75 \mathrm{mM}$ TME (Tris- $\mathrm{HCl}, \mathrm{pH} 7.4,2 \mathrm{~mm}$ EDTA, and $12.5 \mathrm{~mm}$ $\mathrm{MgCl}_{2}$ ). Total binding in each animal was assayed in triplicate, and background binding was assayed in single or duplicate samples. Data were analyzed by two-tailed unpaired Student's $t$ test using Statview II.

cAMP accumulation assay. The four interdigital pads were removed from the hind feet of adult or P21 rats. Each pad was cut into three pieces and preincubated for $30-60 \mathrm{~min}$ at $37^{\circ} \mathrm{C}$ in serum-free medium (SFM; Habecker et al., 1995) supplemented with $4 \mathrm{~mm}$ ED'IA to inhibit phosphodiesterase activity. The incubation was continued for $30 \mathrm{~min}$ in control SFM or medium supplemented with drugs as indicated. Samples were then placed on ice, sonicated for $10 \mathrm{sec}$, and boiled for $5 \mathrm{~min}$. Proteins were removed by centrifugation, the supernatant was recovered, and CAMP accumulation was determined using a cAMP assay system from Amersham. Data were analyzed by Anova using Statview II.

Phosphoinositide hydrolysis assay. Footpad tissue was dissected from P20 and adult rats, and individual pads were cut into three smaller pieces. Tissue from two pads was pooled for each treatment condition and preloaded with SFM containing $6 \mu \mathrm{Ci} / \mathrm{ml}\left[{ }^{3} \mathrm{H}\right]$ myo-inositol at $37^{\circ} \mathrm{C}$ for 6 $\mathrm{hr}$. Tissue was rinsed three times and preincubated for $30 \mathrm{~min}$ in $200 \mu \mathrm{l}$ of PSS (118 mM NaCl, $4.7 \mathrm{~mm} \mathrm{KCl,} 3 \mathrm{mM} \mathrm{CaCl}_{2}, 1.2 \mathrm{mM} \mathrm{MgSO}_{4}, 1.2 \mathrm{~mm}$ $\mathrm{KH}_{2} \mathrm{PO} 4,10 \mathrm{~mm}$ glucose, $0.5 \mathrm{~mm}$ EDTA, $20 \mathrm{~mm}$ HEPES, pH 7.4, and 10 $\mathrm{mM} \mathrm{LiCl}$ ) at $22^{\circ} \mathrm{C}$. The incubation was continued for $1 \mathrm{hr}$ with either control PSS or PSS supplemented with drugs as indicated. Reactions were terminated by the addition of $0.75 \mathrm{ml}$ of methanol and chloroform (2:1), and inositol phosphate accumulation was determined as described previously (Pfaffinger et al., 1988).

Animals. To denervate footpads, unilateral sciatic nerve lesions were performed as described previously (Grant et al., 1991). Binding studies were carried out with footpads from the operated and control side of adult animals 1 week after sciatic nerve lesion. In developing animals denervated on postnatal day 20 , similar results were obtained in binding assays performed either 2 or 3 weeks after surgery. To prevent development of the sympathetic nervous system, newborn rats were injected for $7 \mathrm{~d}(\mathrm{P} 1-\mathrm{P} 7)$ with $100 \mathrm{mg} / \mathrm{kg}$ of the sympathetic neurotoxin 6-hydroxydopamine (6-OHDA) or an equal volume of vehicle $(0.9 \% \mathrm{NaCl}, 1 \mathrm{~mm}$ ascorbate). This treatment eliminates sympathetic innervation of sweat glands (Yodlowski et al., 1984). To perturb muscarinic cholinergic transmission specifically, P20 rat pups were implanted with Alzet miniosmotic pumps releasing $20 \mathrm{mg} \cdot \mathrm{kg}^{-1} \cdot \mathrm{d}^{-1}$ the muscarinic antagonist L-atropine for $14 \mathrm{~d}$. This dose of atropine is sufficient to block cholinergic responsiveness in sweat glands (Grant et al., 1995), and blockade was confirmed by sweating assay on the last day of drug release. 
Immunohistochemistry. VIP- and CGRP-immunoreactive innervation of footpads was examined in sympathectomized animals using immunohistochemistry. To prepare sections, sympathectomized adult rats were killed by ether inhalation and perfused with $4 \% p$-formaldehyde in $0.1 \mathrm{M}$ sodium phosphate for $10 \mathrm{~min}$. Hind footpads were removed, fixed in $4 \%$ $p$-formaldehyde for an additional hour, and cryoprotected overnight in $30 \%$ sucrose $/ 0.1 \mathrm{~m}$ sodium phosphate. Ten micrometer sections were affixed to gelatin-coated slides, rinsed in PBS, and incubated overnight at room temperature in dilution buffer $(0.5 \mathrm{M}$ sodium chloride, $0.01 \mathrm{M}$ sodium phosphate, $3 \%$ bovine serum albumin, $0.1 \%$ sodium azide, $0.3 \%$ Triton $\mathrm{X}$ ) with $5 \%$ rat serum, guinea pig anti-VIP antiserum (1:300 dilution), and rabbit anti-CGRP antiserum (1:500 dilution). Sections were then rinsed in PBS, incubated for $2 \mathrm{hr}$ at room temperature with secondary antisera conjugated to fluorophores (rhodamine isothiocyanate-conjugated goat anti-guinea pig and fluorescein-conjugated goat anti-rabbit), diluted 1:200 in dilution buffer containing 5\% rat serum, and rinsed again with PBS before examination by fluorescence microscopy.

\section{RESULTS}

\section{Rat footpads express three classes of adrenergic receptor mRNA}

There are three general classes of adrenergic receptors: $\alpha 1, \alpha 2$, and $\beta$ (Kobilka, 1992). Several subtypes exist within each class of receptor, and their tissue distributions can vary widely. To determine which types of adrenergic receptors were present in rat footpads, we designed subtype-specific PCR primers based on rat cDNA sequences for the $\alpha 1 \mathrm{~B}, \alpha 2 \mathrm{~B}, \beta 1$, and $\beta 2$ receptors. Reverse transcription and PCR amplification of RNA isolated from postnatal day 4 (P4), P7, P10, P14, P21, and adult rat footpads revealed the presence of only $\alpha 1 \mathrm{~B}, \alpha 2 \mathrm{~B}$, and $\beta 2$ mRNAs, although all PCR primers amplified bands of the appropriate size from rat brain cDNA (Fig. 1) (Habecker and Landis, 1994). Northern analysis indicated that the mRNA encoding $\alpha 1$ receptors is decreased in adult footpads (Fig. 1B).

\section{$\alpha 1$ and $\beta$ receptors are localized to sweat glands}

Because rat footpads contain several tissues in addition to sweat glands, radioligand autoradiography was used to ascertain which tissues within the footpad expressed adrenergic receptors. Although this technique does not provide the resolution needed to distinguish between myoepithelial and secretory cells within the sweat glands, it can identify receptors present in sweat glands rather than the surrounding tissue. Binding studies were performed on sections of footpad tissue from P10, P14, and adult rats. $\alpha 1$ receptors were identified by $\left[{ }^{125} \mathrm{I}\right]$ HEAT binding, $\alpha 2$ receptors were identified by $\left[{ }^{125} \mathrm{I}\right] \mathrm{PIC}$ binding, and $\beta$ receptors were identified by $\left[{ }^{125} \mathrm{I}\right]$ pindolol binding. $\alpha 1$ binding was observed in P14 but not adult animals and was localized to sweat glands (Fig. 2). $\beta 2$ binding also was localized to sweat glands and was observed in P10 animals (Habecker and Landis, 1994), and at lower levels in adults (Fig. 3). In contrast to the selective localization of $\alpha 1$ and $\beta 2$ receptors, specific $\alpha 2$ binding, defined as that blocked by selective antagonists, was present in both P14 and adult footpads but was not localized to sweat glands (Fig. 4, and data not shown). Instead, it was distributed sparsely throughout the footpad, possibly associated with connective tissue cells.

\section{Expression of $\alpha 1$ and $\beta 2$ receptors decreases in adults}

To quantify the developmental changes in $\alpha 1$ and $\beta$ receptor levels observed by autoradiography, and to confirm the presence of specific $\alpha 2$ binding, expression of adrenergic receptors was measured in membrane homogenates of sweat gland-containing footpad tissue. Sweat gland tissue was removed from the rear footpads of $\mathrm{P} 21$ and adult rats for binding analysis. $\alpha 1$ receptor expression underwent a striking change, dropping from $202 \pm 20$

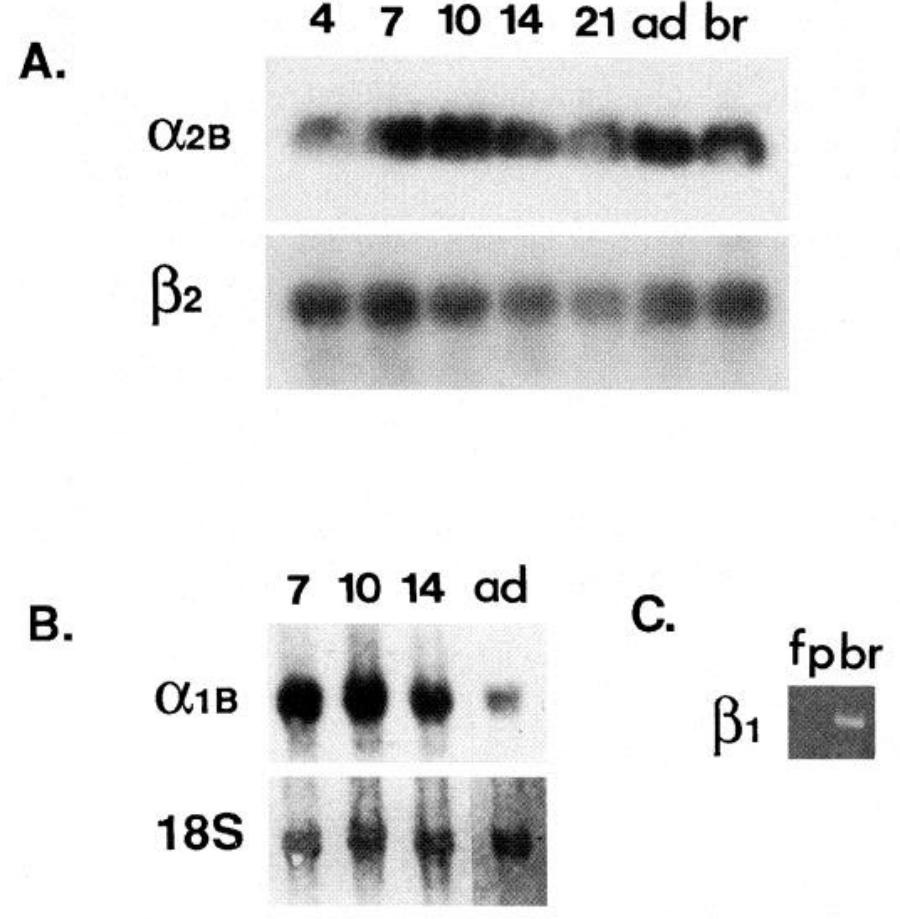

Figure 1. mRNA encoding $\alpha 1 \mathrm{~B}, \alpha 2 \mathrm{~B}$, and $\beta$ adrenergic receptors are present in rat footpads. $A$, Amplification of $\alpha 2 \mathrm{~B}$ and $\beta 2$ adrenergic receptor mRNA. Total RNA isolated from adult brain $(b r)$ and footpads $(f p)$ from postnatal day 4 (P4), 7, 10, 14, 21, and adult animals was reversetranscribed, and adrenergic receptor mRNA amplified using subtypespecific primers. $\alpha 2 \mathrm{~B}$ (top) and $\beta 2$ (bottom) receptor mRNAs were amplified by PCR and identified by Southern blot with ${ }^{32} \mathrm{P}$-tailed 30 -mer oligonucleotide probes. Reactions were carried out with RNA from at least three different animals at each age. $B$, Identification of $\alpha 1 \mathrm{~B}$ receptor mRNA. Ten microgram samples of total RNA from P7, P10, P14, and adult rat footpads were subjected to Northern blot analysis. The blot was stained with methylene blue $(18 S)$ and then hybridized with a ${ }^{32} \mathrm{P}$-tailed $\alpha 1$-specific oligonucleotide probe. RNA preparations from at least three animals at each age gave similar results. $C$, Amplification of $\beta 1$ adrenergic receptor mRNA. Total RNA isolated from adult footpad $(f p)$ and brain (br) was reverse-transcribed, and $\beta 1$ mRNA was amplified using subtypespecific primers.

fmol/mg to just $41 \pm 5$, a fivefold difference (Fig. 5). $\beta 2$ receptors also fell, from a high of $224 \pm 19$ at P21 to $124 \pm 11 \mathrm{fmol} / \mathrm{mg}$ in adults, whereas $\alpha 2$ levels were close to $100 \mathrm{fmol} / \mathrm{mg}$ at both ages. These changes were consistent with the developmental decrease in $\alpha 1$ mRNA observed by Northern analysis (Fig. 1) and with the decreased $\alpha 1$ and $\beta 2$ binding detected by receptor autoradiography (Fig. 3).

\section{Sweat gland adrenergic receptors stimulate production of second messengers}

Although ligand binding indicates that adrenergic receptors are present in sweat glands, several other proteins are needed for these receptors to generate intracellular signals. Adrenergic receptors can regulate a variety of molecules; among the best characterized responses are $\beta$ stimulation and $\alpha 2$ inhibition of adenylyl cyclase activity and $\alpha 1$ activation of phospholipase C. To determine whether the receptors present in developing (P20, P21) and adult sweat glands were functional and whether the lower level of $\alpha 1$ and $\beta$ receptors present in adults resulted in decreased responsiveness, we measured the ability of receptor agonists to regulate intracellular cAMP and inositol phosphate accumulation. 

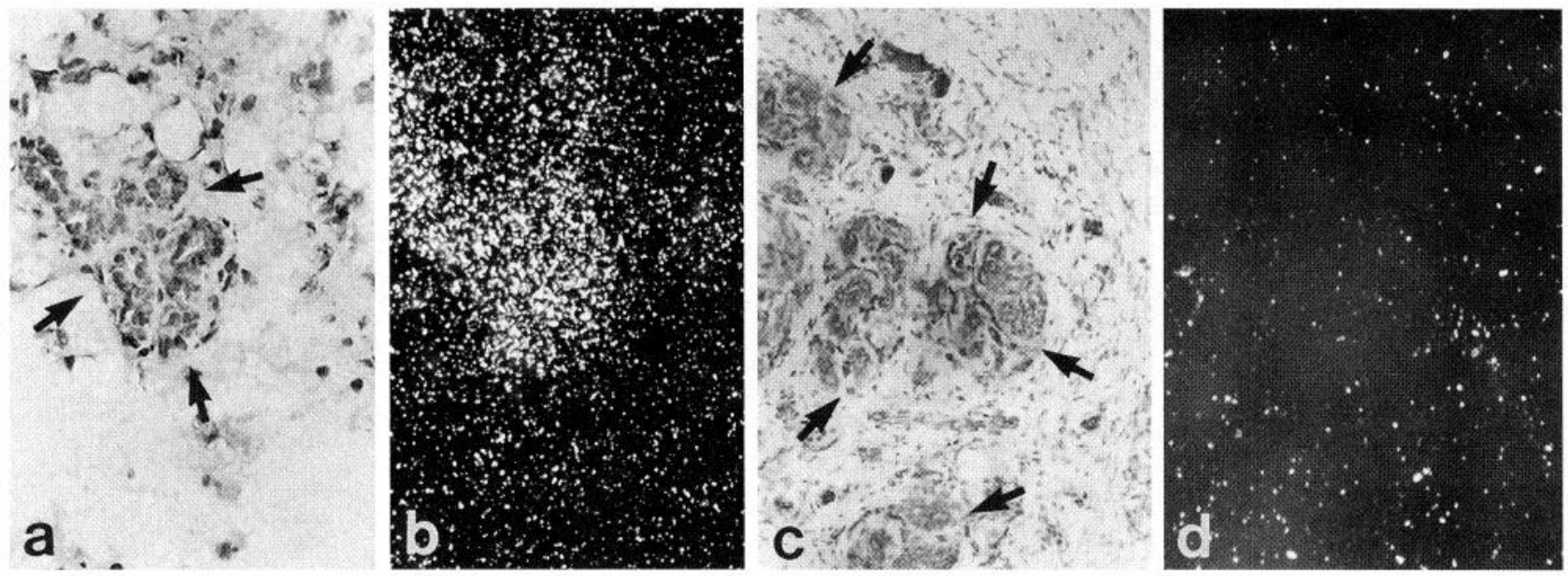

Figure 2. $\alpha 1$-binding sites are localized to sweat glands in rat footpad. Ten micron sections of P14 $(a, b)$ and adult $(c, d)$ rat footpad were incubated in $50 \mathrm{pM}\left[{ }^{125} \mathrm{I}\right] \mathrm{HEAT}$ with or without $20 \mu \mathrm{M}$ prazosin and processed for autoradiography. $a, c$, Bright field of footpad sections with cresyl violet-stained glands (arrows). $b, d$, Dark field reveals the corresponding [ ${ }^{125} \mathrm{I}$ ]HEAT binding. Specific binding in sweat glands was blocked by $20 \mu \mathrm{M}$ prazosin (data not shown). Autoradiograms were exposed for $2 \mathrm{~d}$, magnification $48 \times$.

$\beta$-mediated stimulation and $\alpha 2$-mediated inhibition of cAMP production was tested using the $\beta$ agonist isoproterenol and the $\alpha 2$ agonist $\rho$-amino clonidine. Treatment of footpad explants with isoproterenol resulted in increased cAMP accumulation in P21 (216 $\pm 34 \%$ of control, $n=4)$ and adult animals $(293 \pm 31 \%$ of control, $n=6$ ) (Fig. 6A). This response was blocked significantly by the $\beta$ antagonist propranolol, but was not decreased significantly by the $\alpha 2$ agonist $\rho$-amino clonidine (Fig. 6A), although an initial experiment indicated that $\rho$-amino clonidine inhibited forskolin-stimulated adenylyl cyclase activity (fold increase: forskolin, $40 \pm 2$; forskolin/ $\rho$-AC, $22 \pm 0.7$ ). Neither the stimulation of cAMP production nor its basal level was altered significantly by the $50 \%$ decrease in $\beta$ receptor levels (basal: P21 $=24.5 \pm 5.1$ $\mathrm{pmol} / \mathrm{mg}, n=4 \pm \mathrm{SEM}$; adult $=17.8 \pm 1.8 \mathrm{pmol} / \mathrm{mg}, n=6 \pm$ SEM), suggesting that receptor number was not the limiting factor in cAMP production.

$\alpha 1$-induced activation of phospholipase $\mathrm{C}$ activity was measured in footpad tissue from P20 and adult animals using carbacholinduced stimulation of phospholipase $\mathrm{C}$ as a control (Grant and Landis, 1991). Treatment of P20 sweat gland explants with $1 \mathrm{~mm}$ norepinephrine increased the activity of phospholipase $\mathrm{C}$ to $359 \pm$ $46 \%$ ( $n=10 \pm$ SEM) of control, but treatment of adult footpads with norepinephrine increased inositol phosphate accumulation to only $163 \pm 13 \%(n=9 \pm$ SEM) of control (Fig. $6 B)$. In contrast, treatment of tissue with carbachol induced similar increases in inositol phosphate accumulation ( $\sim 400 \%$ of control) at both P20 and adult. Although these experiments did not address directly whether there were developmental alterations in other components of the signaling pathways used by adrenergic receptors, the retention of carbachol responsiveness suggested that the decreased responsiveness to norepinephrine in adults was because of the lower level of $\alpha 1$ receptors in adult footpads.

\section{Innervation differentially regulates adrenergic receptor expression}

To determine whether the sweat gland sympathetic innervation affected adrenergic receptor expression during development, neonates were sympathectomized with the neurotoxin 6-OHDA during the first postnatal week, which prevents sympathetic axons from reaching the footpad. Footpads from sympathectomized and control adults were then assayed for the presence of adrenergic receptors. The lack of sympathetic innervation had no effect on the level of $\alpha 2$ or $\beta$ receptor expression in adult animals (Fig. 7A). Likewise, the absence of sympathetic innervation during development has no detectable effect on expression of muscarinic receptors in sweat glands, which mediate sympathetic stimulation of sweat secretion (Grant and Landis, 1991; Grant et al., 1991).

In contrast, sweat glands from sympathectomized adults re-
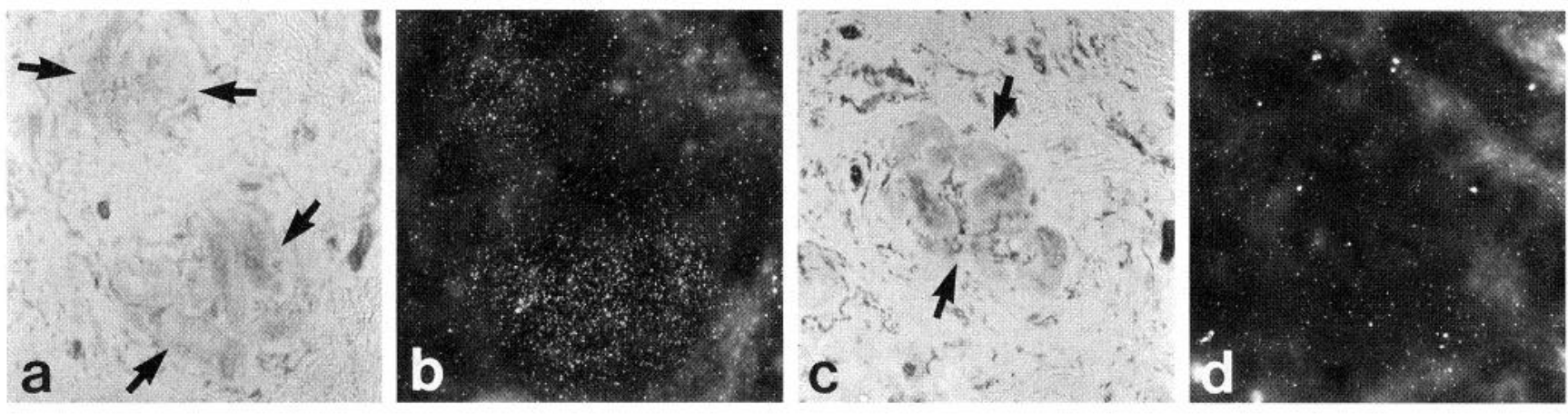

Figure 3. $\beta$-binding sites are localized to sweat glands in adult rat footpad. Ten micron sections of adult rat footpad were incubated with 50 pM $\left[{ }^{125} \mathrm{I}\right]$ pindolol with or without $10 \mu \mathrm{M}$ propranolol as described, and were processed for autoradiography. Bright-field $(a, c)$ views show sweat glands (arrows) stained with cresyl violet, and the corresponding dark-field views show total $(b)$ and background $(d)$ binding. Autoradiograms were exposed for 2 d, magnification $48 \times$. 

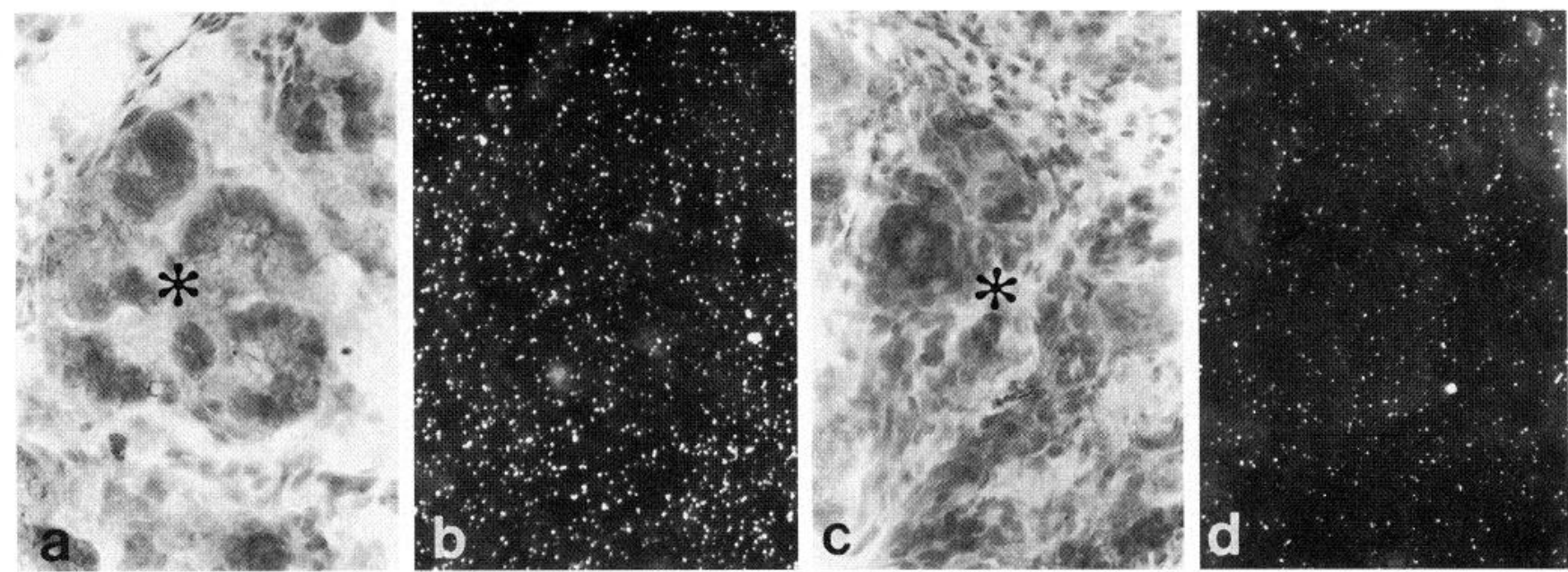

Figure 4. $\alpha 2$-binding sites are not localized to sweat glands in P10 rat footpad. Ten micron sections of P10 rat footpad were incubated in $10 \mathrm{nM}\left[{ }^{125} \mathrm{I}\right] \mathrm{PIC}$ with or without $10 \mu \mathrm{M}$ yohimbine and processed for autoradiography. Bright-field $(a, c)$ views show sweat glands stained with cresyl violet (asterisks), and the corresponding dark-field views show total $(b)$ and background $(d)$ binding. Autoradiograms were exposed for $2 \mathrm{~d}$, magnification $96 \times$.

tained significantly more $\alpha 1$ receptors than their vehicle-injected counterparts (Fig. $7 B$ ), and this was accompanied by increased retention of $\alpha 1$ mRNA (Fig. $7 C$ ). The lack of sympathetic innervation had no effect, however, on the expression of $\alpha 1$ receptors at $\mathrm{P} 21$, when receptor expression is still high (Fig. 7B). Because catecholamines ordinarily are present in the sweat gland sympathetic innervation only before P21, these results suggested that catecholamines did not influence expression of adrenergic receptors in sweat glands. We could not exclude, however, the possibility that the lack of catecholamines earlier in development influenced $\alpha 1$ expression in adults. Therefore, rats were subjected to unilateral sciatic nerve lesion at P20 after catecholamines were no longer detectable, and $\alpha 1$ binding was assayed in control and denervated footpads 2 or 3 weeks later. The removal of cholin-

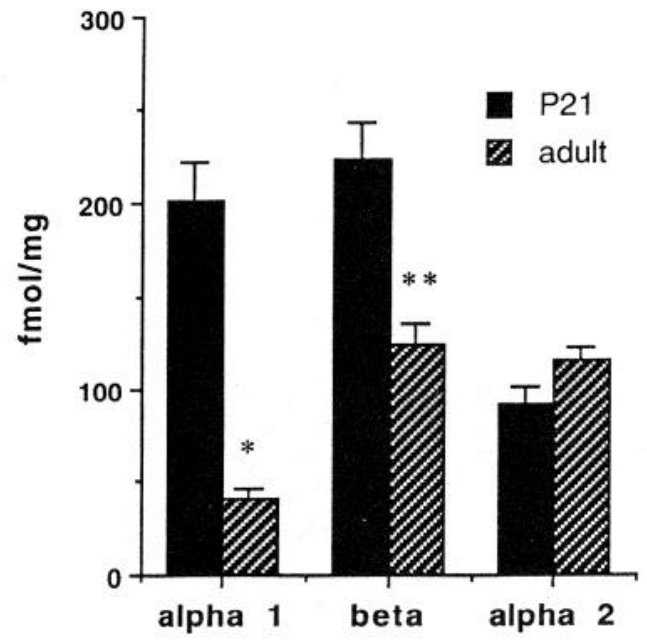

Figure 5. Developmental decrease in $\alpha 1$ and $\beta$ receptor levels. Membrane homogenates of sweat gland tissue from the rear footpads of adult or P21 rats were assayed for the presence of adrenergic receptors by radioligand binding. Solid bars indicate binding in P21 animals: $\alpha 1,202 \pm$ $20 \mathrm{fmol} / \mathrm{mg}(n=10) ; \beta, 224 \pm 19 \mathrm{fmol} / \mathrm{mg}(n=16) ; \alpha 2,91 \pm 11 \mathrm{fmol} / \mathrm{mg}$ $(n=11)$. Hatched bars represent adult animals: $\alpha 1,41 \pm 4.8 \mathrm{fmol} / \mathrm{mg}(n$ $=14) ; \beta, 124 \pm 11 \mathrm{fmol} / \mathrm{mg}(n=14) ; \alpha 2,116 \pm 6 \mathrm{fmol} / \mathrm{mg}(n=4)$. Data shown are the average of $(n)$ animals, \pm SEM. $\alpha 1\left({ }^{*} p<0.0001\right)-$ and $\beta$ $\left({ }^{* *} p<0.003\right)$-binding sites decreased significantly between P21 and adulthood, and the level of $\alpha 2$ receptors remained similar. ergic and peptidergic innervation by surgical denervation at P20 caused retention of a similar fraction of $\alpha 1$ receptors, as did neonatal sympathectomy (Fig. 8). This retention indicated that the innervation-dependent portion of the developmental decrease in $\alpha 1$ receptors was mediated by the mature sympathetic innervation, which produces acetylcholine as well as VIP and CGRP.

\section{$\alpha 1$ expression is not influenced by acetylcholine}

Acetylcholine, which induces secretory responsiveness in sweat glands (Grant et al., 1995), seemed a likely candidate to influence the developmental pattern of $\alpha 1$ expression. To determine whether acetylcholine was involved in this process, P20 rats were implanted with miniosmotic pumps releasing $20 \mathrm{mg} \cdot \mathrm{kg}^{-1} \cdot \mathrm{d}^{-1}$ of the muscarinic antagonist L-atropine, a dose sufficient to block muscarinic receptors in sweat glands (Grant et al., 1995). Blockade was confirmed on the 14 th day after pump implantation, the last day of drug release, when animals were assayed for their ability to sweat in response to pilocarpine. Systemic doses of atropine in treated animals were sufficient to block the pilocarpine-induced sweating response that was evident in control animals (data not shown). Footpads were removed the next day from treated and control animals and assayed for the presence of $\alpha 1$ receptors. Cholinergic blockade had no effect on the developmental decrease in $\alpha 1$ expression (Fig. 8), indicating that acetylcholine did not mediate the innervation-dependent regulation of $\alpha 1$ development.

The observation that acetylcholine did not control $\alpha 1$ receptor levels suggested that either VIP or CGRP was responsible for the innervation-dependent decrease in $\alpha 1$. Immunohistochemistry revealed that sympathectomy induced sprouting of CGRP-containing cutaneous sensory fibers, so that CGRP was readily detected in contact with sweat glands, whereas VIP was absent (Fig. 9). Sympathectomy and P20 denervation both appeared to deprive sweat glands of a signal necessary to induce the complete downregulation of $\alpha 1$ receptors. Because CGRP was still present in one of these conditions, VIP appeared to be a more likely potential mediator of the innervation-dependent portion of $\alpha 1$ receptor loss. Reverse transcription of footpad RNA followed by amplification with primers specific for the VIP receptor (Ishihara et al., 1992), which also has been referred to as the type II PACAP receptor (Spengler et al., 1993), indicated that mRNA encoding 
A.

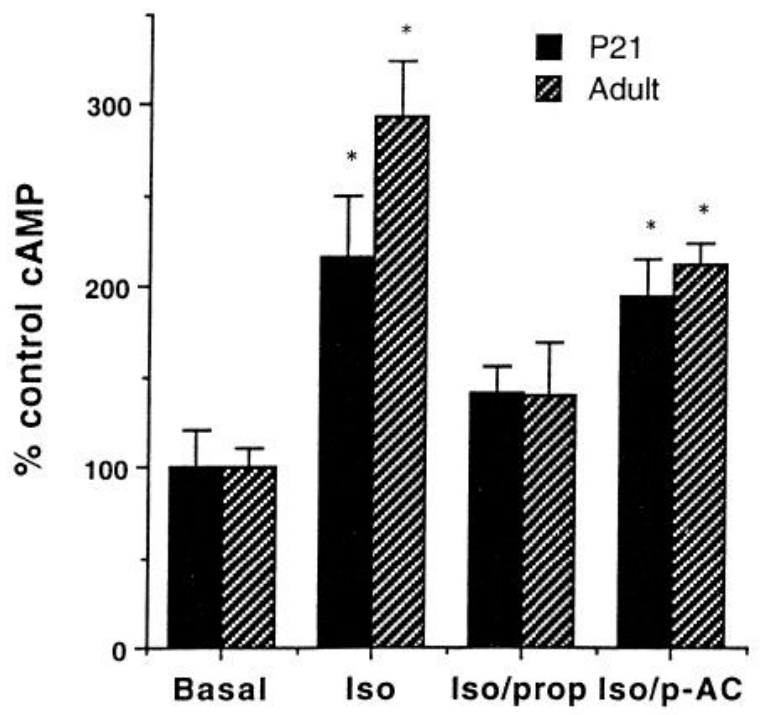

B.

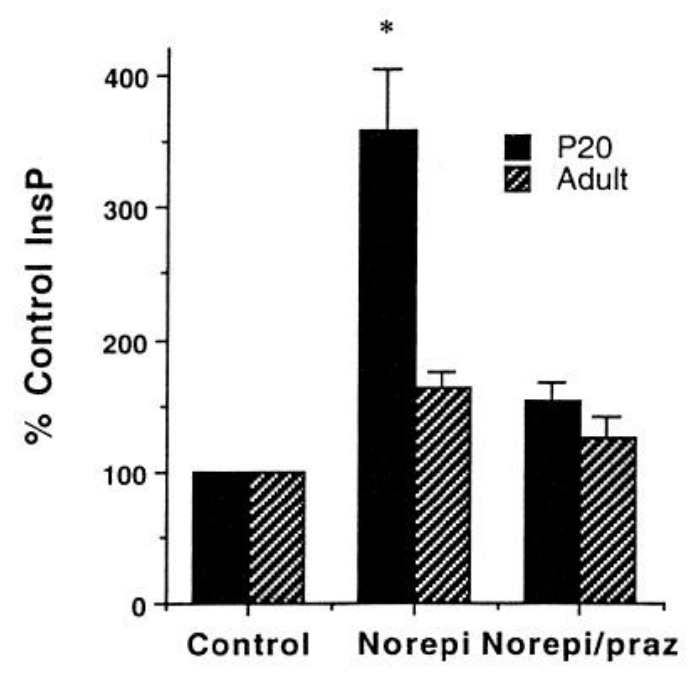

Figure 6. Sweat gland adrenergic receptors are functionally coupled. $A, \beta$ receptor stimulation of cAMP production. Sweat gland tissue was removed from $\mathrm{P} 21$ (solid bars) and adult (hatched bars) rats and incubated at $37^{\circ} \mathrm{C}$ for $1 \mathrm{hr}$ with control SFM or SFM with $100 \mu \mathrm{M}$ isoproterenol, $100 \mu \mathrm{M}$ isoproterenol plus $10 \mu \mathrm{M}$ propranolol, or $100 \mu \mathrm{M}$ isoproterenol plus $100 \mu \mathrm{M}$ $\rho$-aminoclonidine. cAMP accumulation was then measured as described. Data shown represent the mean \pm SEM of three to seven experiments, each assayed in duplicate. Basal levels of cAMP were $24.5 \pm .5 .1 \mathrm{pmol} / \mathrm{mg}$ in P21 animals and $17.8 \pm 1.8 \mathrm{pmol} / \mathrm{mg}$ in adult animals. Asterisks indicate values significantly higher than basal $\left({ }^{*} p<0.03\right)$. $B$, Stimulation of phosphotidylinositol breakdown. Sweat gland tissue from P20 (solid bars) and adult (hatched bars) animals was preloaded with $\left[{ }^{3} \mathrm{H}\right] m y o$-inositol and treated with control SFM, SFM with $1 \mathrm{~mm}$ norepinephrine, or SFM with $1 \mathrm{~mm}$ norepinephrine plus $10 \mu \mathrm{M}$ prazosin for $1 \mathrm{hr}$ at $22^{\circ} \mathrm{C}$. Total inositol phosphate accumulation was measured as described. Data shown represent the mean \pm SEM of 9 or 10 experiments. Norepinephrine induced greater inositol phosphate accumulation in P20 animals $(359 \pm 46 \%)$ than in adults $(163 \pm 13 \%)$, and this was blocked by the $\alpha 1$ antagonist prazosin (P20, $154 \pm 14 \%, n=3$; adult, $126 \pm 15 \%, n=2$ ).

the VIP receptor was expressed in footpad tissue throughout development (Fig. 9). This suggested that sweat glands were responsive to VIP, but it remains unclear whether VIP regulates $\alpha 1$ expression.
A.

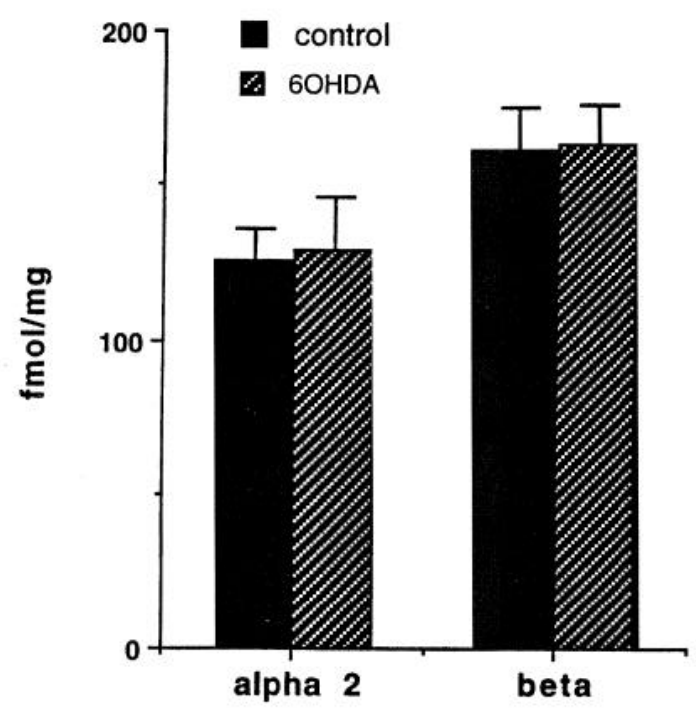

B.

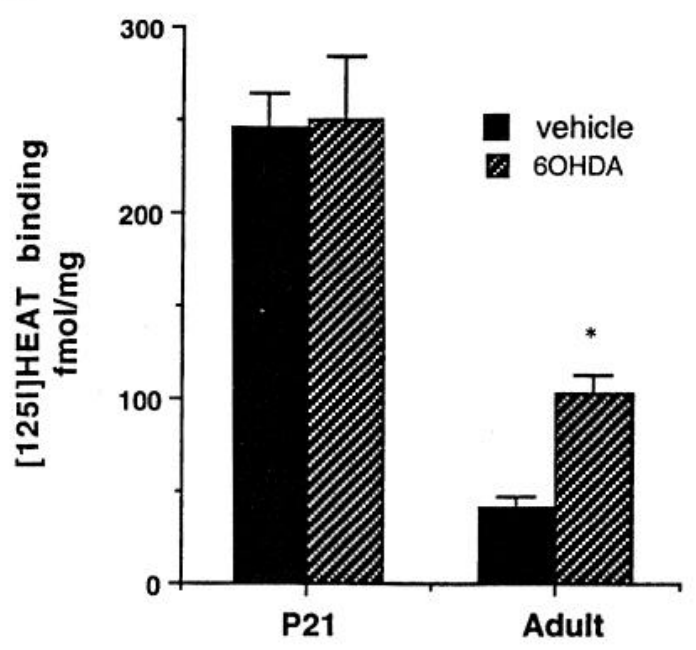

C.

$\alpha_{1 \mathrm{~B}}$

$18 S$

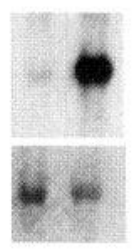

Figure 7. Sympathectomy regulates receptor expression in a subtypeselective manner. Animals were injected with the sympathetic neurotoxin 6-hydroxydopamine (6-OHDA) or with saline vehicle from P1 to P7. Membrane homogenates from the rear footpads of control (solid bars) and sympathectomized (hatched bars) rats were assayed for the presence of adrenergic receptors by radioligand binding. $A$, Sympathectomy had no effect on the level of $\alpha 2$ or $\beta$ adrenergic receptors. Data shown are the average of at least four animals, \pm SEM. $B$, Sympathectomy did not alter $\alpha 1$ expression in P21 footpads ( $n=2$ or $3, \pm \mathrm{SD}$ ), but resulted in significantly higher $\alpha 1$ levels in adult footpads (vehicle, $42 \pm 6 \mathrm{fmol} / \mathrm{mg} ; 6-\mathrm{OHDA}, 103 \pm 10 \mathrm{fmol} / \mathrm{mg} ; n=7$ \pm SEM, ${ }^{*} p<0.0002$ ). Data shown are the average of $(n)$ animals. $C$, Sympathectomy also regulates $\alpha 1 \mathrm{~B}$ mRNA expression in rat footpad. $\alpha 1 \mathrm{~B}$ mRNA was identified by Northern blot in total RNA isolated from control (left) and sympathectomized (right) adult rat footpads using an $\alpha 1 \mathrm{~B}$-specific probe. The blot shown is representative of results obtained with RNA from four sympathectomized animals and four control animals. 


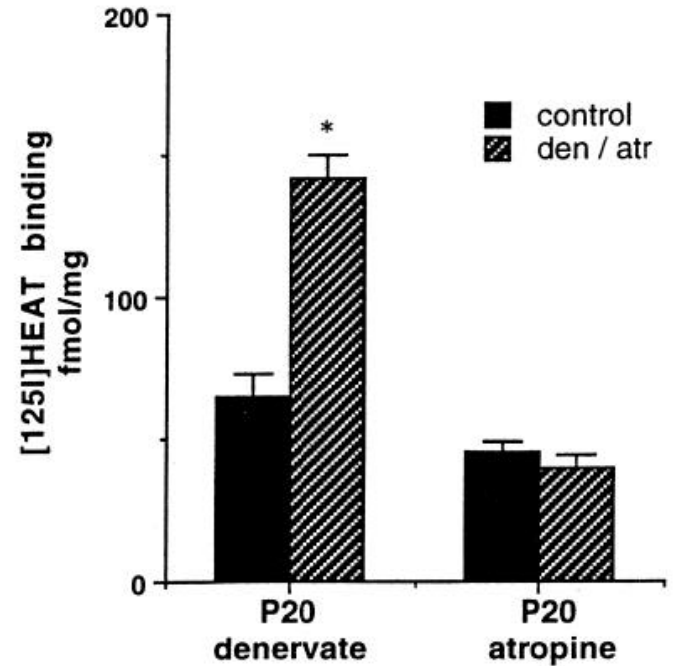

Figure 8. Sciatic nerve transection and cholinergic blockade differentially regulate adult $\alpha 1$ levels. Rats were denervated by unilateral sciatic nerve lesion on postnatal day $20(P 20)$ or, alternatively, P20 rats were implanted with miniosmotic pumps releasing $20 \mathrm{mg} \cdot \mathrm{kg}^{-1} \cdot \mathrm{d}^{-1}$ atropine to block cholinergic transmission specifically. Sweat gland tissue was collected 2 weeks later for quantitation of $\left[{ }^{125} \mathrm{I}\right]$ HEAT binding. Data shown are the average of seven animals, $\pm \mathrm{SEM}\left({ }^{*} p<0.0001\right)$.

\section{Denervation of adult sweat glands does not alter expression of adrenergic receptors}

Because the absence of innervation early in development differentially regulates expression of adrenergic receptors, we tested whether the loss of innervation altered adrenergic receptor levels in adult rats. Unilateral sciatic nerve lesions were performed on
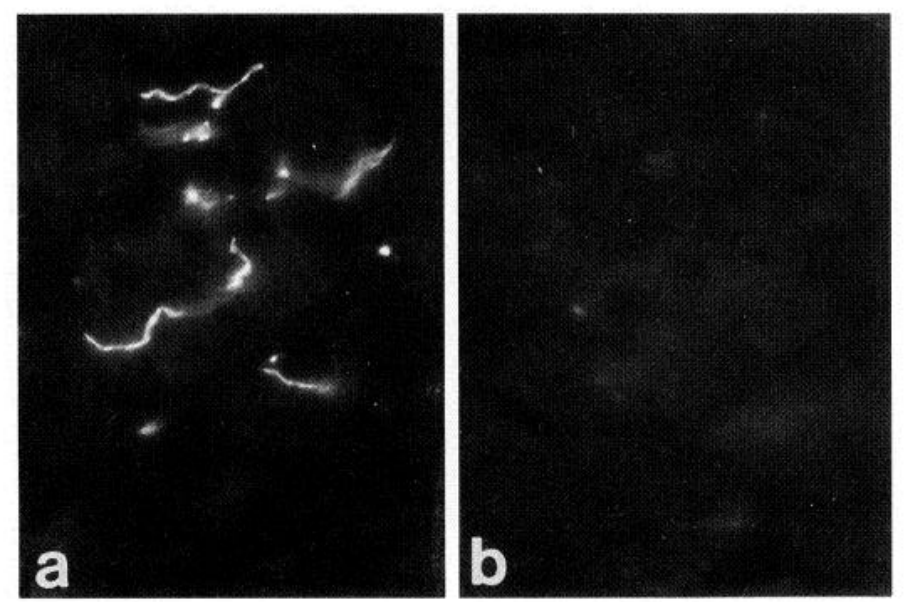

C

Figure 9. Sympathectomy removes VIP- but not CGRP-immunoreactive fibers from sweat glands; mRNA encoding the VIP receptor is present in footpads. Ten micron sections of footpad tissue from sympathectomized rats were double-labeled for CGRP $(a)$ and VIP $(b)$ immunoreactivity. No VIP-positive fibers were visible, but CGRP-immunoreactive fibers innervate the sweat glands. $c$, Total RNA isolated from footpads at (left to right) P4, 7, 10,14, 21, and adult was reverse-transcribed, and VIP receptor mRNA was amplified by PCR and identified by Southern blot. Reactions were carried out with RNA from at least three different animals at each age.

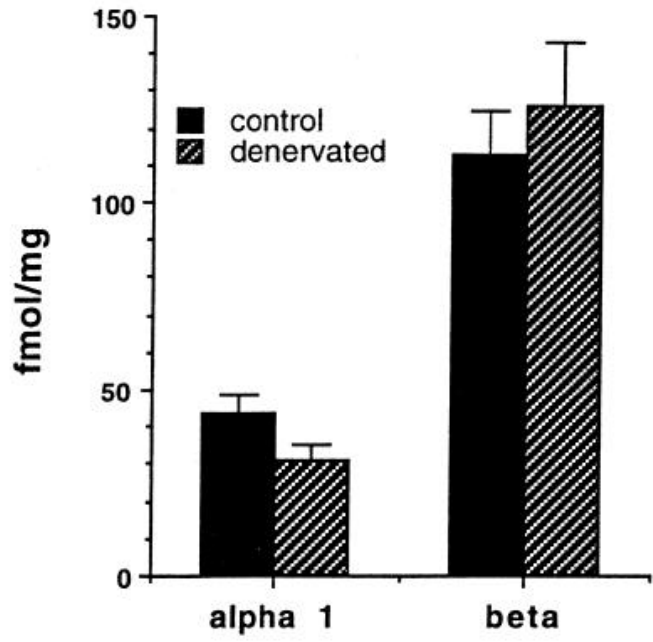

Figure 10. Sciatic nerve transection in adults has little effect on the level of footpad adrenergic receptors. Adult animals were subjected to unilateral sciatic nerve transection to denervate one of the rear footpads. One week after surgery, the control and denervated footpads from each animal were removed and adrenergic receptors were quantified by radioligand binding in membrane homogenates. The loss of innervation did not significantly $(p>0.05)$ alter the level of $\alpha 1(n=9 \pm$ SEM) or $\beta(n=4$ \pm SEM) adrenergic receptors present in adult footpads.

adult rats, and rear footpads were assayed $7 \mathrm{~d}$ later for the presence of $\alpha 1$ and $\beta 2$ adrenergic receptors. Denervation of adult footpads did not alter significantly the level of either $\alpha 1$ or $\beta$ receptors present 1 week later, suggesting that innervation is not critical for maintaining the mature level of receptor expression (Fig. 10).

\section{DISCUSSION}

Three types of adrenergic receptors are present in rat footpads, and each has a unique pattern of expression during development. Two of these, $\alpha 1$ and $\beta 2$, are localized specifically to sweat glands and decrease in the 2 weeks after postnatal day 21 . In contrast, $\alpha 2$ receptors, which are present in nonepidermal tissues throughout the footpad, do not undergo developmental downregulation. The differential pattern of receptor expression observed in sweat glands is not surprising in itself, because each adrenergic receptor subtype has a unique pattern of expression during development (Chen et al., 1979; Ludford and Talamo, 1981; Latifpour and Bylund, 1983; Cutler et al., 1985). The decrease in $\alpha 1$ and $\beta 2$ receptors is unusual, however, because it coincides with a phenotypic switch in the gland innervation. Although the sweat gland sympathetic innervation initially releases the adrenergic agonist norepinephrine, by P21 it no longer makes catecholamines but produces acetylcholine, VIP, and CGRP (Landis and Keefe, 1983; Landis et al., 1988). Thus, the removal of catecholamines precedes a decrease in adrenergic receptor levels and a corresponding decrease in agonist-induced phospholipase $\mathrm{C}$ activity. This contrasts with previous studies that indicate that removal of catecholamines by chemical or surgical sympathectomy results in increased receptor expression and agonist supersensitivity in both developing and adult animals (Yamada et al., 1980; Tenner et al., 1982; Chess-Williams et al., 1987, 1994). In addition, in vitro studies indicate that the presence of agonist results in downregulation of receptors and desensitization of responsiveness, whereas the removal of agonist results in upregulation of receptors and supersensitivity (Raymond et al., 1990; Collins et al., 1991, 1992). Thus, the loss of catecholamines during normal development does 
not affect receptor expression in the same manner as does removal of catecholamines by sympathectomy, denervation, or administration of exogenous agonists or antagonists.

Although expression of adrenergic receptors in sweat glands does not follow the pattern one would expect based on in vitro studies of receptor regulation, the observation that decreased receptor levels coincide with changes in the sympathetic innervation suggests that the innervation influences receptor expression. Removal of the developing sympathetic innervation by injecting neonates with the neurotoxin 6-OHDA does not affect, however, the levels of $\alpha 2, \beta 2$, or $\mathrm{m} 3$ muscarinic (Grant and Landis, 1991) receptors; nor does it alter the expression of $\alpha 1$ receptors through P21. Thus, when the sweat gland sympathetic innervation produces catecholamines (P4-P21), expression of adrenergic receptors is not influenced by the innervation, but instead is directed by an intrinsic developmental program or by non-neuronal environmental influences.

Whereas the noradrenergic innervation does not alter adrenergic receptor levels in sweat glands, the mature cholinergic and peptidergic sympathetic innervation does differentially regulate receptor expression. Both neonatal sympathectomy, which prevents development of the sympathetic innervation, and surgical denervation at $\mathrm{P} 20$, which removes the cholinergic and peptidergic sympathetic innervation, result in increased retention of $\alpha 1$ receptors in adult animals. The lack of innervation only partially prevents the developmental downregulation of $\alpha 1$ receptors, however, indicating that an innervation-independent mechanism also controls $\alpha 1$ expression. Because sweat glands contain both secretory and myoepithelial cells (Landis and Keefe, 1983; Quick et al., 1984 ), this may reflect a partial rescue of $\alpha 1$ expression in all cells or complete retention of $\alpha 1$ in one cell type but not the other. Autoradiography with iodinated ligands does not permit resolution of individual cells, so we cannot distinguish between these two possibilities. In either case, removal of the cholinergic and peptidergic sympathetic innervation deprives sweat glands of a signal that partially inhibits production of $\alpha 1$ adrenergic receptors. This complex regulation of $\alpha 1$ expression contrasts with the innervation-independent expression of $\alpha 2, \beta 2$, and $\mathrm{m} 3$ receptors and suggests that the innervation-dependent aspect of $\alpha 1$ development is mediated through a heterologous mechanism.

The mature sweat gland innervation produces acetylcholine, VIP, and CGRP, and it is likely that one of these molecules mediates the innervation-dependent regulation of $\alpha 1$ expression. Blockade of cholinergic transmission with systemic atropine does not attenuate the loss of $\alpha 1$ receptors, indicating that acetylcholine does not inhibit expression of $\alpha 1$ receptors. This suggests that either VIP or CGRP mediates the innervation-dependent receptor loss, although we cannot exclude the possibility that other anterograde signals released by some neurons, such as acetylcholine receptor-inducing activity (Chu et al., 1995) or ATP (vonKugelgen et al., 1994), influence receptor expression. Likewise, we cannot rule out the possibility that circulating epinephrine alters receptor levels, although this is unlikely because the level of circulating epinephrine is not sufficient to induce production of an innervation-dependent sweat gland-derived differentiation factor (Habecker and Landis, 1994). If a neuropeptide is involved in $\alpha 1$ regulation then VIP is the more likely candidate, because neonatal sympathectomy, which causes increased retention of $\alpha 1$ receptors in adults, results in the loss of VIP-positive innervation in sweat glands but causes sprouting of CGRP-containing sensory neurons into the glands. The correlation between the presence of VIP in the sweat gland innervation and decreased $\alpha 1$ receptors in sweat glands is surprising, because VIP activates adenylyl cyclase (Gozes and Brenneman, 1989), and culture studies indicate that cAMP increases $\alpha 1 \mathrm{mRNA}$ and receptor expression. In DDT MF-2 vas deferens cells, direct activation of adenylyl cyclase or addition of cAMP analogs increases $\alpha 1$ mRNA transiently, and chronic treatment of cells with agents that increase cAMP results in upregulation of $\alpha 1$ receptors over several days (Morris et al., 1991).

The control of sweat gland $\alpha 1$ receptor expression by nonadrenergic sympathetic innervation appears to be similar to the regulation of muscarinic receptor development by noradrenergic sympathetic innervation in the chick expansor secundariorum muscle. These muscarinic receptors urdinarily are lost during development, but muscarinic downregulation is abolished by removal of the noradrenergic input (Bennett et al., 1982; Rush et al., 1982), just as in sweat glands $\alpha 1$ adrenergic downregulation is altered by removal of cholinergic-peptidergic innervation. In both systems, receptor expression is regulated by innervation that does not release the transmitter corresponding to the receptor, but in the expansor muscle there is essentially no decrease in muscarinic receptors after denervation. In sweat glands, however, half of the $\alpha 1$ receptors present at $\mathrm{P} 21$ are still lost, indicating that an innervationindependent mechanism also regulates $\alpha 1$ levels.

The developmental expression of adrenergic receptors in sweat glands is subject to differential regulation. There are striking differences both in the expression of specific subtypes and in the way these developmental changes are initiated, because $\beta$ receptors all decrease in an innervation-independent manner, whereas $\alpha 1$ receptors undergo both innervation-dependent and innervation-independent downregulation. In addition, the effect of the sympathetic innervation on receptor expression is not mediated by an adrenergic agonist, but rather may work through activation of neuropeptide receptors in sweat glands. The molecular basis for these expression patterns is not yet understood, but the mechanisms that have been elucidated in culture studies of agonistinduced downregulation and antagonist-induced upregulation cannot account for the developmental changes in adrenergic receptor levels in sweat glands. This raises the possibility that receptor regulation during development is equally complex in other tissues, and it highlights the difficulty of extrapolating developmental mechanisms from reduced systems. Alterations in receptor expression during development influence cellular sensitivity to extracellular signals that can subsequently affect the developmental process. There is a further level of complexity in this process with respect to signaling, because the downstrcam components also are subject to developmental and second-messenger-mediated regulation.

Although the underlying mechanisms responsible for receptor regulation remain to be defined, it is clear that the correct expression of adrenergic receptors is important for sweat gland development. Activation of these receptors in sweat glands leads to the production of a cholinergic differentiation factor, which induces the noradrenergic to cholinergic-peptidergic switch in the sympathetic innervation. After the innervation undergoes this phenotypic change, production of the differentiation factor becomes innervation-independent (our unpub lished observations) whereas the cholinergic innervation induces secretory responsiveness in sweat glands (Grant et al., 1995). The presence and functional coupling of adrenergic 
receptors is critical during the first few weeks of postnatal sweat gland development when they are most highly expressed. These receptors downregulate to lower levels when the innervation stops making catecholamines and adrenergic receptors no longer mediate the effects of sympathetic stimulation, although activation of $\beta$ receptors by exogenous agonists can elicit a small but detectable sweating response (Stevens and Landis, 1987). The developmental changes in adrenergic receptor expression provide further evidence that a complex set of interactions using both intrinsic and environmental signals guides the differentiation of autonomic target tissues and the sympathetic neurons that innervate them.

\section{REFERENCES}

Bennett T, Lot TY, Strange PG (1982) The effects of noradrenergic dencrvation on muscarinic receptors in smooth musclc. Br J Pharmacol $76: 177-183$.

Buckland PR, Hill RM, Tidmarsh SF, McGuffin P (1990) Primary structure of the rat beta-2 adrenergic receptor gene. Nucleic Acids Res 18:682.

Chen FM, Yamamura HI, Roeske WR (1979) Ontogeny of mammalian myocardial beta-adrenergic receptors. Eur J Pharmacol 58:255-264.

Chess-Williams RG, Broadley KJ, Sheridan DJ (1987) Cardiac postjunctional alpha 1- and beta-adrenoceptors: effects of chronic chemical sympathectomy with 6-hydroxydopamine. J Recept Res 7:713-728.

Chess-Williams RG, Doubleday B, Reynolds GP (1994) Differential regulation of cardiac $\alpha$ - and $\beta$-adrenoceptors by the sympathetic nervous system. J Auton Pharmacol 14:29-36.

Chu GC, Moscoso LM, Sliwkowski MX, Merlie JP (1995) Regulation of the acetylcholine receptor epsilon subunit gene by recombinant ARIA: an in vitro model for transsynaptic gene regulation. Neuron 14:329-339.

Collins S, Caron MG, Lefkowitz RJ (1991) Regulation of adrenergic receptor responsiveness through modulation of receptor gene expression. Annu Rev Physiol 53:497-508.

Collins S, Caron MG, Lefkowitz RJ (1992) From ligand binding to gene expression: new insights into the regulation of G-protein-coupled receptors. Trends Biochem Sci 17:37-39.

Cutler LS, Schneyer C, Christian C (1985) The influence of the sympathetic nervous system on the development of $\beta$-adrenergic. Arch Oral Biol 30:341-344.

Chomczynski P, Sacchi N (1987) Single-step method of RNA isolation by acid-guanidinium thiocynate-phenol-chloroform extraction. Anal Biochem 162:156-159.

Gilman AG (1987) G-proteins; transducers of receptor-generated signals. Annu Rev Biochem 56:615-650.

Gozes I, Brenneman DE (1989) VIP: molecular biology and neurobiological function. Mol Neurobiol 3:201-236.

Grant MP, Francis NJ, Landis SC (1995) The role of acetylcholine in regulating secretory responsiveness in rat sweat glands. Mol Cell Neurosci $6: 32-42$.

Grant MP, I andis SC (1991) Developmental expression of muscarinic cholinergic receptors and coupling to phospholipase $C$ on rat sweat glands are independent of innervation. J Neurosci 11:3772-3782.

Grant MP, Landis SC, Siegel RE (1991) The molecular and pharmacological properties of muscarinic cholinergic receptors expressed by rat sweat glands are unaltered by denervation. J Neurosci 11:3763-3771.

Habecker BA, Landis SC (1994) Noradrenergic regulation of cholinergic differentiation. Science 264:1602-1604.

Habecker BA, Tresser SJ, Rao MS, Landis SC (1995) Production of sweat gland cholinergic differentiation factor depends on innervation. Dev Biol 167:307-316.

Hadcock JR, Port JD, Malbon CC (1991) Cross-regulation between G protein-mediated pathways. J Biol Chem 266:11915-11922.

Inglese J, Freedman NJ, Koch WJ, Lefkowitz RJ (1993) Structure and mechanism of the $\mathrm{G}$ protein-coupled receptor kinases. I Biol Chem 268:23735-23738.
Ishihara T, Shigemoto R, Kensaku M, Takahashi K, Shigekazu N (1992) Functional expression and tissue distribution of a novel receptor for vasoactive intestinal polypeptide. Neuron 8:811-819.

Kobilka B (1992) Adrenergic receptors as models for G protein-coupled receptors. Annu Rev Neurosci 15:87-114.

Landis SC (1990) Target regulation of neurotransmitter phenotype. Trends Neurosci 13:344-350.

Landis SC, Keefe D (1983) Evidence for neurotransmitter plasticity in vivo: developmental changes in the properties of cholinergic sympathetic neurons. Dev Biol 98:349-372.

Landis SC, Schwab M, Siegel RE (1988) Evidence for neurotransmitter plasticity in vivo: II. Immunocytochemical studies of rat sweat gland innervation during development. Dev Biol 126:129-138.

Latifpour J, Bylund DB (1983) Characterization of adrenergic receptor binding in rat lung: physiological regulation. J Pharmacol Exp Ther 224:186-192.

Lee NH, Fraser CM (1993) Cross-talk between m1 muscarinic acetylcholine and beta 2-adrenergic receptors. J Biol Chem 268:7949-7957.

Ludford JM, Talamo BR (1981) Independent regulation of beta-adrenergic receptor and nucleotide binding proteins of adenylate cyclase. $\mathrm{J}$ Biol Chem 258:4831-4838.

Machida CA, Bunzow JR, Searles RP, Van Tol J, Tester B, Neve KA, Teal P, Nipper V, Civelli O (1990) Molecular cloning and expression of the rat $\beta 1$-adrenergic receptor gene. J Biol Chem 265:12960-12965.

Milano CA, Allen LF, Rockman HA, Dolber PC, McMinn TR, Chien KR, Johnson TD, Bond RA, Lefkowitz RJ (1994) Enhanced myocardial funclion in transgenic mice overexpressing the $\beta 2$-adrenergic receptor. Science 264:582-586.

Morris GM, Hadcock JR, Malbon CC (1991) Cross-regulation between G protein-coupled receptors. J Biol Chem 266:2233-2238.

Pfaffinger PJ, Leibowitz MD, Subers EM, Nathanson NM, Almers W, Hille B (1988) Agonists that suppress M-current elicit phosphoinositide turnover and calcium transients, but these events do not explain M-current suppression. Neuron 1:477-484.

Quick DC, Kennedy WR, Yoon KS (1984) Ultrastructure of the secretory epithelium, nerve fibers and capillaries on the mouse sweat gland. Anat Rec 208:491-499.

Raymond JR, Hnatowich M, Lefkowitz RJ, Caron MG (1990) Adrenergic receptors: models for regulation of signal transduction processes. Hypertension 15:119-131.

Rush RA, Crouch MF, Morris CP, Gannon BJ (1982) Neural regulation of muscarinic receptors in chick expansor secundariorum muscle. Nature 296:569-570.

Spengler D, Waeber C, Pantaloni C, Hoisboer F, Bockaert J, Seeburg PH, Journot L (1993) Differential signal transduction by five splice variants of the PACAP receptor. Nature 365:170-175.

Stevens LM, Landis SC (1987) Development and properties of the secretory response in rat sweat glands: relationship to the induction of cholinergic function in sweat gland innervation. Dev Biol 123:179-190.

Tenner TE, Mukherjee A, Hester RK (1982) Reserpine-induced supersensitivity and the proliferation of cardiac $\beta$-adrenoceptors. Eur $\mathrm{J}$ Pharmacol 77:61-65.

Voigt MM, Kispert J, Chin HM (1990) Sequence of a rat cDNA encoding an alpha-1B adrenergic receptor. Nucleic Acids Res 18:1053.

von-Kugelgen I, Allgaier C, Schobert A, Starke K (1994) Co-release of noradrenaline and ATP from cultured sympathetic neurons. Neuroscience 61:199-202.

Yamada S, Yamamura HI, Roeske WR (1980) Characterization of alpha-1 adrenergic receptors in the heart using $\left[{ }^{3} \mathrm{H}\right] \mathrm{WB} 4101$ : effect of 6-hydroxydopamine trcatment. J Pharmacol Exp Ther 215:176-185.

Yodlowski ML, Fredieu JR, Landis SC (1984) Neonatal 6-hydroxydopamine treatment eliminates cholinergic sympathetic innervation and induces sensory sprouting in rat sweat glands. J Neurosci 4:1535-1548.

Zeng D, Harrison JK, D'Angelo DD, Barber CM, Tucker AL, Lu Z, Lynch KR (1990) Molecular characterization of a rat $\alpha 2 B$-adrenergic receptor. Proc Natl Acad Sci USA 87:3102-3106.

Zhang J-F, Robinson R, Siegelbaum S (1992) Sympathetic neurons mediate developmental change in cardiac sodium channel gating through long-term neurotransmitter action. Neuron 9:97-103. 